\title{
MODELY NÁKUPNÉHO SPRÁVANIA OBYVATELOV MESTSKÝCH ČASTÍ MESTA TRNAVA
}

\author{
Miroslava Trembošová, Marta Máčajová, Matej Močko
}

\begin{abstract}
The main aim of the contribution is a focuses on shaping and classification of shopping behaviour. Behavioural survey helped us to describe shopping behaviour of the Trnava citizens on the level of town suburbs in 2015. Assessing the survey of shopper types used according to the Czech methodology called "Shopper typology media behaviour" we find out the orientation of Trnava citizens according to a random sample of 1818 respondents. The practical part of the thesis includes shaping of the shopping behaviour that was stated by our respondents by means of contingency coefficient.
\end{abstract}

Keywords: Trnava city, shopping behaviour, models of shopping behaviour, contingency coefficient

\section{Úvod}

Nákupné správanie je významný sociologický fenomén chápaný ako prejav konzumného spôsobu života do značnej miery ovplyvnený societou, v ktorej konzument využíva tovary a služby. Zahŕňa dôvody, ktoré vedú zákazníka k tomu, aby sa stal spotrebitel'om určitého produktu (tovaru/služby). Miera konzumného správania je ovplyvňovaná dostupnost'ou tovaru, kultúrou predaja, ponukou predajných konceptov, reálnymi príjmami domácností, životným štýlom a marketingovými aktivitami predajcov. Ovplyvňuje nielen ekonomiku, ale má i výrazné sociálne a kultúrne prejavy. V špecifických prípadoch má tiež dôležitú priestorovú funkciu $\mathrm{v}$ zmysle spádovitosti $\mathrm{k}$ vybranému nákupnému centru (Trembošová a kol., 2016).

Ciel’om nášho príspevku je poznanie nákupného správania obyvatel'ov mesta Trnava. Na základe výsledkov dotazníkového prieskumu stanovíme modely nákupného správania respondentov a respondentiek podla veku prostredníctvom koeficientu kontingencie. Zároveň potvrdíme resp. vyvrátime hypotézu, že obyvatel'stvo mesta Trnava sa v nakupovaní správa moderne.

\section{Teoreticko-metodické východiská}

Práce v oblasti geografie maloobchodu zamerané na sociologické aspekty nákupného správania a jeho zmeny vplyvom vel'koplošných predajní majú silný interdisciplinárny charakter. Pri jej výskumu vzniká dôležitá spolupráca medzi 
geografmi, ekonómami, sociológmi, kultúrnymi antropológmi a kultúrnymi historikmi. V d’alšom texte uvádzame práve tých, ktorí nás najviac a ovplyvnili jednak pri metodike práce, jednak svojimi myšlienkami a poznaním pravdy o spotrebitel'skom správaní.

Tejto problematike sa intenzívne venujú ekonómovia napr. Teller a Elms (2012), Teller a Thomson (2010), Teller, Elms, Thomson a Padison (2010), Teller a Kotzab (2004). Európski ekonómovia vytvorili medzinárodné kolokvium Cerro, ktoré je zamerané na prezentáciu výsledkov najnovších výskumov zameraných na porozumenie správania spotrebitel'ov a navrhovanie jednotlivých operácií, logistiky a kanálov na ich dosiahnutie.

$\mathrm{Na}$ Slovensku našlo spotrebitel'ské správanie odozvu vekonomických prácach Hamalovej (1996), Štofilovej (2003), Meteňku (2007), Kitu a Grosmannovej (2014). Na Slovenskej pol'nohospodárskej univerzite bol v roku 2014 na Fakulte ekonomiky a manažmentu spustený projekt „Využitie neuromarketingu vo vizuálnom merchandisingu potravín“, ktorý bol ukončený vytvorením Laboratóriá spotrebitel'ských štúdií (17.10.2018), ktoré je jedinečné v strednej Európe. Sledovanie neuromarketingových emočných signálov sledovaných osôb a postupy empirickej štúdie zlúčil autor tohto laboratória Jakub Berčík do dvoch patentov a do vedeckej monografie Berčík a Horská (2017). Autori naznačujú, že každé rozhodovanie človeka (aj nákupné) je v prvom rade emocionálne a až neskôr racionálne zdôvodnené. Tieto závery vychádzajú z teórie amerického psychológa a neurológa Antonia Damasio. Berčík hovorí o multipercepcii, teda širokom spektre podnetov, ktoré ovplyvňujú rozhodovanie človeka pri obyčajnom nákupe. Laboratórium bude využívat' poznanie lekárskej vedy - neurológie, psychológie v spojení s informatikou na analýzu správania spotrebitel'ov a, samozrejme, vytvárat' analýzy pre obchod a výrobcov, čo majú urobit' pre to, aby si naklonili zákazníkov na svoju stranu.

Sociologické práce z oblasti nákupného správania si všímajú aspekty a prejavy konzumného spôsobu života. Existuje niekol'ko zaujímavých prác sledujúcich rozdiely medzi nákupným správaním muža a ženy (Firat, 1993), pričom častejšie, z pochopitel'ných dôvodov, sú pozorované ženy. „Ženy často nakupujú s ciel'om sa o niekoho starat' alebo niekoho potešit'. Zatial' čo muži nakupujú výhodne, so zl’avou, s výhodou“ (Otnes a McGrath, 2001).

Tiež atribúty vyhl'adávania pri výbere nákupného miesta sú odlišné pre mužov a pre ženy. Ženy dávajú prednost’ atribútom spojených s atmosférou centra, kvalitou obsluhy, čistotou, vol'ným priestorom, d’alej tiež kvalite nakupovania samotného (výber tovaru, kvalita obchodov či vel'kost' nákupného centra a pod.). „Muži oceňujú predovšetkým kvalitu centra ako je napríklad osvetlenie, rozvrhnutie centra, parkovanie a pod.“ (Dennis, Newman, Marsland, 2005). Uvedení autori vo svojich výskumoch potvrdili, že rozdiely sú tiež medzi l'ud'mi, ktorí jazdia na nákupy automobilom a tými, ktorí využívajú verejnú dopravu. „Tí druhí kladú vy̌šsí dôraz na kvalitu služieb a chovanie predavačov, možnost' posadit' 
sa v centre a oddýchnut' si, na vel'kost' centra, aj na kvalitu za rozumnú cenu“. V zmysle Spilkovej (2012), Križana a kol. (2015), Kunca a kol. (2016) a iných boli empirickými metódami potvrdené rozdiely $\mathrm{v}$ nakupovaní medzi vekovými skupinami. Vel'mi zaujímavá je $\mathrm{v}$ tomto kontexte úloha nákupného centra pri štúdiu staršej populácie. „Starší l’udia vysoko hodnotia možnost' občerstvenia v nákupnom centre. Stále častejšie totiž starší l’udia využívajú nákupné centrá, aby uspokojili potrebu po sociálnych kontaktoch a trávili takto vol'ný čas. Starší l'udia, ktorí nie sú inštitucionalizovaní (v penziónoch či v domovoch sociálnych služieb), skutočne chodia do nákupných centier na prechádzku“ (Spilková, 2012). Analýzou spotrebitel'ského správania vo vzt'ahu k veku respondentov sa zaoberá Jasiulewicz (2012). Oba tieto prístupy (vyhodnocovanie nákupného správania podla pohlavia a veku) sme aplikovali aj my. Jasiulewicz upozorn̆uje aj na ohrozenie kamenných obchodov internetovým obchodom, pričom zákazníci si vyberajú kamennú predajňu na základe dojmu, často pocitu, ktorý autorka považuje za ovel’a dôležitejší ako v prípade internetového obchodu.

Podrobný prehl'ad klasifikácií spotrebitel'ského správania uvádza vo svojej monografii Spilková (2012). Podobne na Slovensku Mitríková (2008) spracovala štúdiu nákupného správania obyvatel’ov miest Prešov a Košice. Nákupné správanie ako sociologický prejav transformácie maloobchodnej siete v meste Nitra sledovala Trembošová $(2009,2010)$. Vyhodnotila a zaradila respondentov do siedmich nákupných typov. Táto metodika bola inšpirujúca aj pre náš empirický prieskum.

V poslednej dekáde zmeny v správaní spotrebitel'ov vo vzt'ahu k priestorovým súvislostiam nachádzajú odozvu v prácach Mitríkovej (2011), Mitríkovej a kol. (2015), Kunca a kol. (2013), Križana a kol. (2015), Bílkovej a kol. (2015), Spilkovej (2016), Trembošovej a kol. (2016). Výber miesta nákupu je najčastejšie analyzovanou doménou v oblasti mobility spotrebitel'ov za službami v priestore v kontexte nákupného spádu Frantál a kol. (2012), Kunc a kol. (2012a, 2012b), Maryáš (2013), Maryáš a kol. (2014), i Szczyrba a Fiedor (2014). Takýto charakter majú aj práce Križana a kol. (2015) i Trembošovej a Dubcovej (2016). Priestorové aspekty maloobchodnej komerčnej suburbanizácie analyzujú v okresoch SR Repaská a kol. (2016a) a v mestských častiach mesta Nitra Repaská a kol. (2016b).

Základnými priestorovými operačnými jednotkami, s ktorými sme pracovali, je 6 mestských častí mesta Trnava: MČ Trnava-Stred, MČ TrnavaZápad, MČ Trnava-Sever, MČ Trnava-Východ, MČ Trnava-Juh a MČ Modranka. Základným nástrojom získania informácií o výbere miesta nakupovania, príjmoch domácností a nákupnom správaní obyvatel'stva v meste Trnava bol dotazník. Respondenti boli oslovovaní mimo nákupných centier, aby nimi neboli priamo ovplyvnení. Miestom anketovania boli najmä zastávky autobusov, okolia križovatiek ciest, pešia zóna, kultúrne podujatia a farmársky trh. Anketa vychádza z poznania, že spotrebitel'ské správanie podl'a rozdielneho chovania rozdel'uje 
zákazníkov na určité skupiny. Analýza sociologicko-nákupných typov oslovených respondentov určuje skupinu nákupnej orientácie, jej vel'kost' a priestorové rozmiestnenie na úrovni mestských častí a trnavskej populácie ako celku. Stanovili sme si hypotézu „nákupné správanie trnavskej populácie bude smerovat' k modernému typu“.

Na zistenie nákupnej orientácie sme využili metódu samourčenia pri otázke: Zakrúžkujte charakteristiku, ktorá najviac vystihuje Vaše nákupné správanie (respondentovi boli vysvetlené charakteristiky jednotlivých nákupných typov, ktoré boli definované firmou GFK Praha, 2015). Pri výbere z uvedených typov mal respondent uviest' len jednu z možností: A) ovplyvnitelný - v nákupnom správaní emotívny, ovplyvnitel'ný reklamou, nakupuje akciový tovar, vel'ké množstvo nákupov počas jedného dňa, B) náročný - má vysoké nároky na kvalitu tovaru a nákupný komfort, C) mobilný pragmatik - optimalizuje pomer medzi cenou a hodnotou tovaru, preferuje vel'koplošné predajne, pravidelne používa auto, $D$ ) opatrný konzervatívec - rozhoduje sa racionálne a konzervatívne, nedôveruje reklame, nepoužíva auto, má nízky podiel impulzívnych nákupov, E) sporivý minimalizuje výdaje, nakupuje racionálne, málo použiva auto, F) lojálny zákazník nakupuje často a v malých množstvách, dáva prednost' menšej predajni v blízkosti bydliska, vyznáva tradíciu, orientuje nakupovanie na sociálnu stránku života, $G$ ) nenáročný flegmatik - nemá na úroveň predajne žiadne nároky, ceny sú mu l'ahostajné, za nákupmi necestuje). Prvé tri typy vytvárajú skupinu modernej nákupnej orientácie, zvyšné štyri tvoria tradičnú nákupnú orientáciu spotrebitel’a.

Behaviorálny prieskum zameraný na nákupné správanie trnavskej populácie prebehol v dňoch 20.-24. apríla 2015 v mestských častiach Trnavy. Bol realizovaný formou dotazníkového prieskumu riadeným rozhovorom študentmi odboru Geografie v regionálnom rozvoji (18 študentov) Katedry geografie a regionálneho rozvoja. Počas štyroch dní v čase od 9:00 do 18:00 bolo náhodným výberom získaných 1818 dotazníkov ( $\mathrm{n}=1818)$, $\mathrm{z}$ toho najviac v MČ Trnava-Sever $(\mathrm{n}=394)$, v MČ Trnava-Východ 381 odpovedí, v MČ Trnava-Západ 352 dotazníkov, v MČ Trnava-Stred 340 odpovedí, v MČ Trnava-Juh 301 dotazníkov a najmenej 50 v MČ Modranka (tab. 15). V odpovediach absentuje nákupné centrum City Aréna, ked’že $\mathrm{v}$ čase dotazovania bolo vo výstavbe (otvorenie až 22.8.2015).

Na sledovanie vzt'ahov a väzieb je dôležité overit', či existuje štatisticky významná závislost’ medzi vybranými znakmi - vekovými skupinami respondentov a ich nákupným typom na úrovni mestských častí. Na určenie závislosti uvedených dvoch kvalitatívnych znakov sme využili Chí-kvadrát $\left(\chi^{2}\right)$ test pre tvorbu kontingenčnej tabul'ky (Markechová a kol. 2011). Intenzitu štatistickej závislosti sme posudzovali pomocou Pearsonovho koeficientu kontingencie, ktorý nám umožnil zistit' stupeň závislosti medzi vybranými pozorovanými znakmi (dosahuje hodnoty $\mathrm{v}$ rozpätí $0,5-1,00$ ) - nákupným typom (znak A) a vekovými skupinami (znak B) podl'a vzt'ahu: 


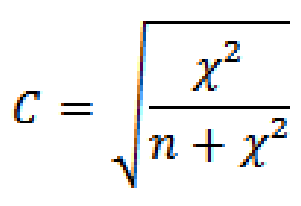

kde

$$
\chi^{2}=\sum_{i=1}^{k} \sum_{j=1}^{m} \frac{\left(f_{i j}-\frac{f_{i}^{A} f_{j}^{B}}{n}\right)^{2}}{\frac{f_{i}^{A} f_{j}^{B}}{n}}
$$

$\mathrm{C}-$ koeficient kontingencie nadobúda hodnoty $\mathrm{z}$ intervalu $\langle 0,1\rangle(\mathrm{ak} \mathrm{C}=0$ potom znaky A, B sú nezávislé, hodnoty blízke nule značia slabú závislost' a naopak, hodnoty blízke 1 silnú závislost'),

$\chi^{2}$ - testovacie kritérium, resp. test dobrej zhody,

$f$ - očakávané početnosti, podávajú informáciu o výsledkoch získaných empiricky,

$\mathrm{n}$ - celková početnost' odpovedí,

$\mathrm{k}$ - triedy početnosti,

A - prvý sledovaný znak (nákupný typ respondenta),

B - druhý sledovaný znak (vek respondenta).

Zo spracovaných údajov sme vyselektovali údaje o veku respondentov a nákupnom type. Súčty jednotlivých vekových kategórií a sledovaného ukazovatel’a sme vynásobili počtom respondentov spadajúcich do danej vekovej kategórie a vydelili celkových počtom dotazovaných. Nadobudnutú hodnotu tzv. reálnu hodnotu vzt’ahu sme použili do rovnice (1-reálna) ${ }^{2}$ : reálna. V rámci sledovaného ukazovatel'a sčítame hodnoty vypočítané na základe spomínaného vzt'ahu podl'a vekových kategórií a spolu pre každý sledovaný typ, vd’aka čomu dostaneme $\chi^{2}$ (Chí-kvadrát), a po dosadení do vzt’ahu koeficientu kontingencie C.

\section{Mesto Trnava a jeho obyvatel'stvo}

Mesto Trnava, najstaršie král'ovské mesto na Slovensku, je mesto so 65596 obyvatel'mi (k 31.12.2015), ležiace medzi riekou Váh a pohorím Malé Karpaty pri toku Trnávka $\mathrm{v}$ oblasti Podunajskej nížiny. Priaznivá poloha na križovatke dávnych ciest bola významným faktorom jej rozvoja. Trnava s rozlohou 71,54 $\mathrm{km}^{2}$ a hustotou 918 obyvatel'ov na $\mathrm{km}^{2}$ je tvorená dvoma katastrálnymi územiami Trnava a Modranka. Mesto Trnava sa člení na 6 mestských častí: MČ Trnava-Stred s rozlohou $2 \mathrm{~km}^{2}$, MČ Trnava-Západ s rozlohou 20,6 km², MČ Trnava-Sever s rozlohou 22,5 km², MČ Trnava-Východ s rozlohou 9,1 km², MČ Trnava-Juh s rozlohou 9,6 km² a MČ Modranka s rozlohou 7,7 $\mathrm{km}^{2}$. Tieto sú zároveň základnými operačnými priestorovými jednotkami našej analýzy, zameranej na nákupné správanie.

Pri skúmaní maloobchodnej siete a nákupného správania jej obyvatel’ov sú informácie o obyvatel'stve dôležitými vstupnými parametrami. Podl'a ŠÚ SR k 31.12. 2015 žilo v meste Trnava 65596 obyvatel'ov, z toho 31669 (48\%) mužov a 
33927 (52 \%) žien. Pozitívna femininita je jav typický pre väčšinu demograficky vyspelých populácií (Bleha, 2003). Ked’že viacero výskumov potvrdilo, že ženy sú ovel'a viac naklonené nakupovaniu a častejšie využívajú maloobchodné služby ako muži, štruktúra obyvatel'stva podl'a pohlavia ovplyvňuje rozvoj maloobchodného podnikania. Proces starnutia obyvatel'stva zhora (zvyšovanie podielu poproduktívneho obyvatel'stva) i zdola (znižovanie podielu predproduktívneho obyvatel'stva), ale aj postupné znižovanie počtu obyvatel'ov v produktívnom veku od roku 2008 sú typické aj pre mesto Trnava. Index starnutia, vyjadrujúci pomer osôb v poproduktívnom veku (60 a starší) na 100 osôb v predproduktívnom veku (0-14 rokov), neustále narastal a v roku 2015 dosiahol hodnotu 107,78\%, kým v roku 2002 to bolo iba 57,2\%. Nad hodnotu 100 vystúpil v roku 2013. Zvyšuje sa aj priemerný vek obyvatel'ov t. j. vážený aritmetický priemer dožitého veku obyvatel'ov. V roku 2002 bol priemerný vek obyvatel'a Trnavy 32,74 roka, v roku 2015 to už bolo 40,76. Hodnoty tohto ukazovatel'a sa odlišujú podl'a pohlavia a sú vyššie u žien. V roku 2002 dosiahol muž priemerný vek 30,79 rokov a žena 34,64, v roku 2015 to bolo u mužov 37,52 a u žien dokonca až 43,93 roka (www.statistics.sk). Priemerný vek Trnavčana sa za 13 rokov zvýšil o 6,73 roka a Trnavčanky až o 9,29 roka, čo taktiež svedčí o starnutí trnavskej populácie, pričom rýchlejšie starne jej ženská zložka. Faktor nevyrovnanej vekovej štruktúry aj v budúcnosti bude pôsobit' na zastúpenie vekových skupín, v najbližších rokoch však v smere starnutia populácie - presun početných kohort do staršieho veku spolu s nízkou základňou vekovej pyramídy. Okrem toho skupinu obyvatel'ov produktívneho veku opúštajú každý rok silné ročníky povojnovej vlny a zvyšujú tak ekonomické zat'aženie produktívneho obyvatel'stva. Nemenej dôležitý je faktor nezamestnanosti (Veselovský, Šolcová, 2011).

\section{Model nákupného správania obyvatel'ov mesta Trnava podl’a mestských častí}

Model nákupného správania v MČ mesta Trnava má svoje špecifiká. Na základe odpovedí respondentov a podl'a najvyššieho počtu zhodných odpovedí vo výbere miesta nakupovania a nákupnom type sme zostavili charakteristiku správania priemerného respondenta v jednotlivých MČ mesta Trnava (Graf 1). Vzhl'adom na dobu dotazníkového šetrenia sa v odpovediach nevyskytuje City Aréna, ktorá bola otvorená o 3 mesiace po realizovaní ankety.

MČ Trnava-Sever má najvyšší priemerný mesačný príjem na 1 osobu (d’alej PMP/osoba) $397 €$. Respondenti nakupujú potraviny v hypermarkete Tesco (27\%) a Lidl (26\%). Oblúbené je nakupovanie drogistického tovaru rovnako v HM Tesco (24\%) a v DM Drogerie (23\%). Za nákupmi spotrebného tovaru cestujú do NAY Elektro (41\%) a do HM Tesco (16\%). Len 5,3\% nakupuje spotrebný tovar cez internet. Až 26\% nakupovalo odevy v HM Tesco, 19\% v ZC Arkadia a 14\% v ZOC Max. Najpreferovanejšou značkou bol u obyvatel'ov MČ Trnava-Sever 
New Yorker 4\% (n=394 respondentov). Aj v oblasti nákupov obuvi bola najoblúbenejším mies-tom nákupov HM Tesco (26\%), nasledovaný ZC Arkadia (19\%) a ZOC Max 14\%. 9\% zákazníkov nakupuje obuv značky Deichmann a 6\% značky Bata. Osobné auto využíva pri nákupoch $39 \%$. V nákupnom správaní sa zarad’ujú $\mathrm{k}$ tradičným $(53 \%)$, pričom najviac respondentov sa stotožňuje so sporivým typom $(22 \%)$.

Graf 1: Nákupná orientácia respondentov podl'a MČ mesta Trnava v r. 2015 Graph 1: Shopping orientation of respondents according to the city of Trnava in 2015

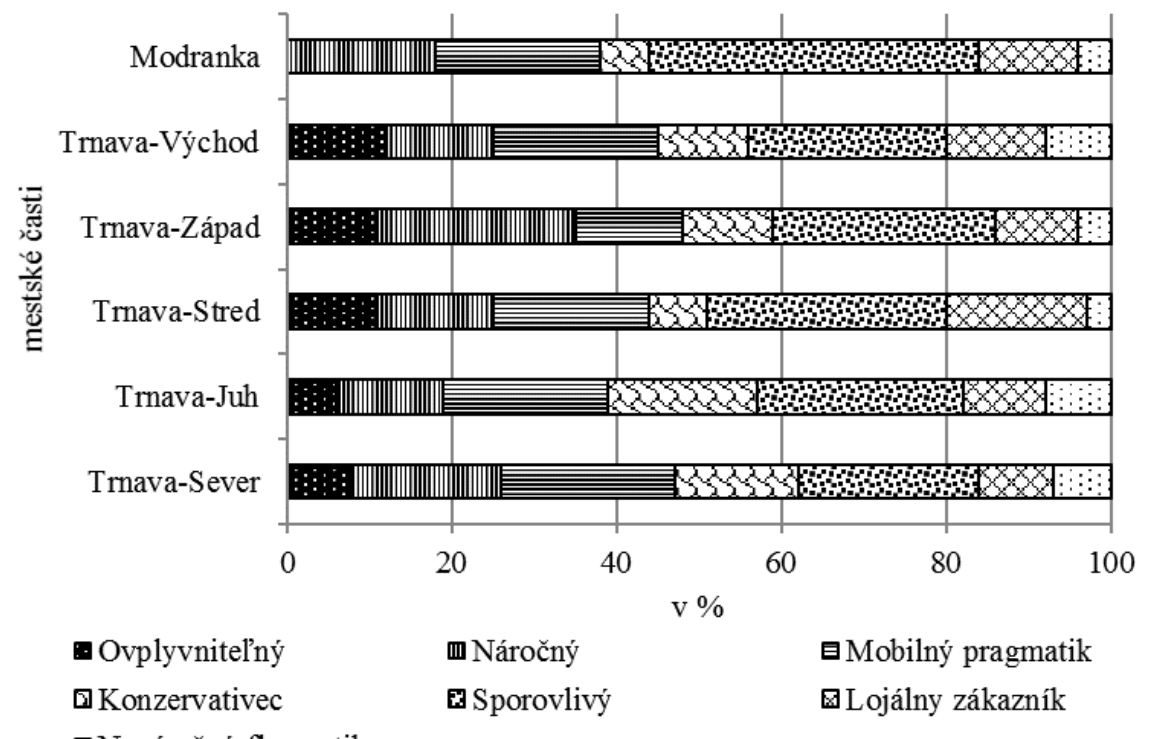

๑Nenáročný flegmatik

$\mathrm{n}=1818$

MČ Trnava-Juh dosiahla podl'a odpovedí 301 respondentov PMP/1 osobu $368 €$. Respondenti uprednostňujú nákupy potravín v COOP Jednota (32\%) a Lidl (25\%). Nákup drogistického tovaru preferujú v COOP Jednota (17\%), ZOC Max a HM Tesco zhodne uviedlo $15 \%$ a zo špecializovaných drogistických predajní uprednostnilo $11 \%$ DM Drogerie. Spotrebný tovar nakupujú najmä v NAY Elektro (35\%) a Planeo Elektro (14\%). Až 37\% respondentov z „Juhu“ odevy nakupuje v ZOC Max a 28\% v HM Tesco, $17 \%$ v rôznych maloplošných predajniach l'udovo nazývaných "butik" a 5\% nakupuje odevy cez internet. Aj v tejto MČ bol vysoko preferovaný odevný ret’azec New Yorker $8 \%$. Výber nákupov obuvi kopíruje výsledky z preferovania odevov. Najoblúbenejším ret’azcom je Deichmann (17\%) a 5\% nakupuje obuv rovnako ako i odevy cez internet. Automobil pri nakupovaní 
využíva 33\%. V nákupnom správaní sa zarad’ujú $\mathrm{k}$ tradičným $(61 \%$ z n=301), najviac respondentov sa stotožňuje so sporivým typom (25\%).

MČ Trnava-Stred má PMP/1 osobu $286 €$. Respondenti v počte 340 uprednostňujú nákupy potravín v predajniach Lidl (36\%), Billa (21\%) a COOP Jednota (14\%) v rámci ich mestskej časti. Prekvapivo nákup drogistických výrobkov nespájajú s nákupom potravín, skôr uprednostňujú DM Drogerie $(37 \%)$ a 101 Drogerie (19\%), menej Lidl (12\%). Presadzuje sa aj retazec TETA (7\%). Podobne i nákupy spotrebného tovaru sú iné ako v ostatných MČ mesta Trnava. Až 124 respondentov (36\%) nakupovalo v predajniach malých živnostníkov, o niečo menej $28 \%$ v NAY Elektro. V nákupoch odevov uprednostňujú ponuku v ZOC Max (34\%) a ako v jedinej mestskej časti až 40 respondentov (12\%) nakupuje odevy u čínskych obchodníkov. Obuv nakupuje $20 \%$ v predajni Bat’a, 12\% v predajni Deichmann a 9\% uviedlo CCC. Rovnaký počet 32 respondentov (9\%) nakupuje obuv u „Č́ńňanov“. Osobný automobil na nakupovanie používa 33\%. V nákupnom správaní sa zarad’ujú $\mathrm{k}$ tradicionalistom (56\%) a najviac $29 \% \mathrm{ku}$ sporovlivému typu.

MČ Trnava-Východ s oslovenými 381 respondentami má PMP/1 osobu druhý najvyšší medzi MČ mesta Trnava - $381 €$. Potraviny nakupujú v Kauflande (33\%) a v Bille (32\%). Z drogistických predajní 32\% zákazníkov uprednostňuje 101 Droge-rie a iné predajne malých živnostníkov $18 \%$. Až na tret'om mieste je DM Drogerie (16\%) a Kaufland s $13 \%$. Nákupy spotrebného tovaru preferujú v NAY (až 55\%) a najvyššie percento $\mathrm{z}$ celého mesta $(31 \%)$ tu žijúcich respondentov nakupuje spotrebný tovar cez internet (z 381 je to 45 respondentov, tzn. 12\%). Až $210(55 \%)$ respondentov tejto MČ pri otázke o nákupoch odevov uviedlo nákupy v ostatných predajniach malých živnostníkov - tzv. butikov, 15\% v HM Tesco a $7 \%$ v čínskych obchodoch., 41\% respondentov nakupuje obuv $\mathrm{v}$ ostatných podnikoch malých živnostníkov. Deichmann je preferenciou 36\% druhou najoblúbenejšou predajňou obuvi a 7\% respondentov preferuje čínske obchody. Osobný automobil pri nákupoch využíva $33 \%$. 22\% respondentov sa v nakupovaní charakterizuje ako sporivý typ s tradičnou orientáciou (55\%).

MČ Trnava-Západ s počtom respondentov 352 má PMP/1 osoba $299 €$. Títo preferujú nákupy potravín v COOP Jednota (29\%) a Billa (28\%). Až 123 (35\%) opýtaných nakupuje drogistický tovar u malých živnostníkov, 15\% v COOP Jednota a rovnako $15 \%$ v 101 Drogerie. Za spotrebným tovarom chodia prednostne do Planeo Elektro (29\%) a 27\% do NAY Elektro. Cez internet nakupuje 11 respondentov (3\%). Za nákupmi odevov smerujú zákazníci z tejto MČ prednostne do ZOC Max (162 opýtaných, tzn. 46\%) a ostatných malých butikov (108 opýtaných, tzn. $31 \%$ ). Podobné percentá sú aj v preferovaní nákupov obuvi, ked' 150 (43\%) opýtaných uprednostňuje ZOC Max a ostatné malé predajne 122 
respondentov (25\%). Podiel motorizovaných pri nákupoch je 37\%. V nakupovaní sú takmer rovnako moderní (49\%) ako i tradiční $(51 \%)$, pričom najviac z nich sa stotožňuje so sporivým typom.

MČ Modranka s najnižším počtom najmenej respondentov 50 má aj najnižší PMP/1 osobu tzn. $204 €$. Za potravinami respondenti tejto okrajovej mestskej časti vidieckeho charakteru nechodia d’aleko, využívajú prednostne predajňu COOP Jednota (27 opýtaných, 54\%). 10 respondentov cestuje za potravinami do Kauflandu (ul. V. Klementisa) v MČ Trnava-Východ. Podobné výsledky sú aj v sekcii drogistického tovaru. Spotrebný tovar nakupujú v ZOC Max (19 opýtaných, 38\%) a rovnaký počet nenakupuje takýto tovar. 4 opýtaní nakupujú cez internet. Zo špecializovaných retazcov uprednostňujú NAY. Odevy i obuv nakupujú v ZOC Max (56\%) a v ostatných malých predajniach (44\%). Osobný automobil používa na nákupy $38 \%$. V nakupovaní sú vel'mi tradiční (62\%), pričom $40 \%$ sa stotožnilo so sporivým typom.

\section{Model nákupného správania podl’a koeficientu kontingencie}

Na sledovanie vzt'ahov a väzieb je dôležité overit', či existuje štatisticky významná závislost’ medzi vybranými znakmi - vekovými skupinami respondentov a ich nákupným typom na úrovni mestských častí. Hodnota testovacieho kritéria Chí-kvadrát sa pohybovala od 47,779 po 333,24 a koeficient kontingencie od 0,5665 po 0,6946 . Závislost' medzi vekom a nákupnými typmi bola potvrdená vo všetkých mestských častiach. Na hranici akceptácie je MČ Trnava-Juh s C=0,5665. Najvyššia overená závislost' bola potvrdená v MČ Trnava-Stred C=0,6946 a MČ Modranka C=0,6849 (tab. 17).

Tab. 1: Ukazovatele testovania závislosti medzi vekom a nákupným typom Table: Dependency test vectors and purchasing type

\begin{tabular}{|l|c|c|c|}
\hline \multicolumn{1}{|c|}{$\begin{array}{c}\text { Mestská } \\
\text { čast' }\end{array}$} & $\begin{array}{c}\text { Počet } \\
\text { respondentov }\end{array}$ & $\begin{array}{c}\boldsymbol{\chi}^{2} \text { - testovacie } \\
\text { kritérium }\end{array}$ & $\begin{array}{c}\text { Koeficient } \\
\text { kontingencie C }\end{array}$ \\
\hline Trnava-Sever & 394 & 333,24 & 0,6764 \\
\hline Trnava-Juh & 301 & 47,779 & 0,5665 \\
\hline Trnava-Stred & 340 & 316,978 & 0,6946 \\
\hline Trnava-Východ & 381 & 299,125 & 0,6636 \\
\hline Trnava-Západ & 352 & 289,644 & 0,6718 \\
\hline Modranka & 50 & 44,071 & 0,6849 \\
\hline
\end{tabular}


Obyvatelia MČ Trnava-Sever do 20 rokov sú v nakupovaní nároční, v kategórii 20-29 roční mobilní pragmatici, 30-39 roční nároční, 40-49 konzervatívni, 50-59 roční sporiví, vo veku 60 a viac lojálni zákazníci. Obyvatelia MČ Trnava-Juh do 20 rokov sú v nakupovaní konzervatívni. 20-29 roční mobilní pragmatici, 30-39 roční taktiež mobilní pragmatici. 40-49 roční mobilní pragmatici, 50-59 roční sporiví a taktiež aj 60 a viac roční. Obyvatelia MČ TrnavaStred do 20 rokov sú sporiví, 20-29 rokov sporiví, 30-39 roční mobilní pragmatici, 40-49 roční sú mobilní pragmatici, 50-59 roční sporiví ako i 60 a viac roční. Obyvatelia MČ Trnava-Východ do 20 rokov sú mobilní pragmatici ako i 20-29 roční a 30-39 roční. 40-49 roční sú rovnako mobilní pragmatici. 50-59 roční sú sporiví ako i 60 a viac roční. Obyvatelia MČ Trnava-Západ do 20 rokov sú sporiví, 30-39 roční sú sporiví, 30-39 roční nároční, 40-49 roční sú nároční, ako i 50-59 roční. 60 a viac roční sú lojálni zákazníci. Obyvatelia Modranky do 20 rokov sú nároční, 20-29 roční mobilní pragmatici, 30-39 roční sú mobilní pragmatici, 40-49 roční sú konzervatívni, 50-59 sporiví ako i 60 a viac roční.

Výsledok kontingencie vzt’ahu medzi vekom a nákupným typom potvrdil, že trnavská populácia je v nakupovaní zatial' tradičná. Z výsledkov rozdelených do 36 skupín (6 vekových kategórií v 6 MČ) vyplýva, že 16 skupín má modernú orientáciu (typy A, B, C, z toho mobilní v 13 variáciách) a 20 má tradičnú $(\mathrm{D}, \mathrm{E}, \mathrm{F}$, $\mathrm{G}, \mathrm{z}$ toho sporiví v 10 podskupinách). $\mathrm{Z}$ detailnejšieho porovnania $\mathrm{v}$ grafe $2 \mathrm{a}$ tab. 2 vyplýva, že trnavská populácia už smeruje k modernému nákupnému správaniu. Najväčšiu variabilitu nákupných typov podla vekových skupín mali dve mestské časti Trnava-Sever a Modranka, kde zo 7 typov boli potvrdené štyri charakteristiky (B, C, D a E).

Graf 2: Model nákupného typu vo vzt'ahu k veku Graph 2: Model type of purchase in relation to age

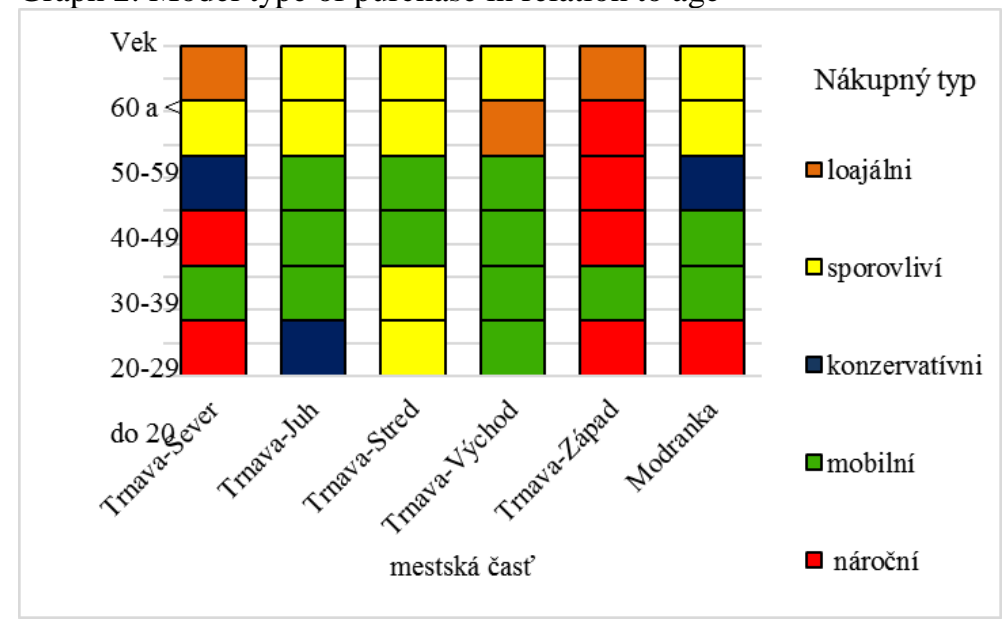


Najmenšie nákupné rozdiely medzi vekovými skupinami boli identifikované v MČ Trnava-Východ, kde obyvatelia vekových skupín od 20 do 49 rokov boli mobilní pragmatici a od 50 a viac sporiví, ako i v MČ Trnava-Stred, kde mladšie ročníky do 29 rokov boli sporiví, 30-49 roční mobilní pragmatici a 50 a viac roční sporiví. V MČ Trnava-Západ sme zistili tri varianty nákupných typov, kde prekvapivo mladšie ročníky do 20 i od 20 do 29 rokov boli v nakupovaní sporiví a naopak ročníky od 30-59 rokov nároční. Najstarší obyvatelia sa ako jediní v meste hlásili k nenáročným flegmatikom. V MČ Trnava-Juh sú prekvapivo mladšie ročníky konzervatívne, v skupine 20-49 roční mobilní pragmatici a 50 a viac roční sporiví.

Tab. 2: Výsledok modelu nákupného správania vo vzt’ahu $\mathrm{k}$ veku

Table 2: The outcome of the model of purchasing behavior in relation to age

\begin{tabular}{|l|c|c|c|c|c|c|}
\hline Mestská čast' & do 20 & $\mathbf{2 0 - 2 9}$ & $\mathbf{3 0 - 3 9}$ & $\mathbf{4 0 - 4 9}$ & $\mathbf{5 0 - 5 9}$ & $\mathbf{6 0}$ a viac \\
\hline Trnava-Sever & B & C & B & D & E & F \\
\hline Trnava-Juh & D & C & C & C & E & E \\
\hline Trnava-Stred & E & E & C & C & E & E \\
\hline Trnava-Východ & C & C & C & C & E & E \\
\hline Trnava-Západ & E & E & B & B & B & F \\
\hline Modranka & B & C & C & D & E & E \\
\hline
\end{tabular}

$A$ - ovplyvnitelní, B - nároční, $C$ - mobilní pragmatici, $D$ - konzervatívci, $E-$ sporiví, $F$-lojálni zákazníci, $G$-nenároční flegmatici

\section{Záver}

Nákupné správanie obyvatel'ov mesta Trnava a jej mestských častí bolo zist'ované na vzorke 1818 respondentov dotazníkovým prieskumom, zameraným na dve oblasti. Prvá bola venovaná výberu miesta nákupu a druhá nákupnej orientácii, vychádzajúc z poznania, že spotrebitel'ské správanie podl'a rozdielneho chovania rozdel'uje zákazníkov na určité skupiny, čo sa prejavilo aj v jednotlivých mestských častiach. Podla sledovaných znakov za „typického“ respondenta nášho výskumu možno považovat' ženu vo veku 40 - 49 rokov, so stredoškolským vzdelaním, zamestnanú, s čistým mesačným príjmom jej dvojčlennej domácnosti $1200-1600 €$.

V modeli nákupného správania respondentov najpočetnejšiu skupinu tvoril sporivý nákupný typ ( $26 \%$ - 473 opýtaných). Na druhom mieste sa umiestnil mobilný pragmatik, ktorého charakteristika bola najvýstižnejšia pre $345(19 \%)$ respondentov a 16\% (291) opýtaných sa zaradilo medzi náročných zákazníkov. Opatrných konzervatívcov bolo $12 \%$ (218 respondentov), na ktorých nadväzuje 
skupina lojálnych nakupujúcich (217, čiže $12 \%)$. Za ovplyvnitel’ných sa považovalo 164 opýtaných (9\%) a do poslednej skupiny nenáročných flegmatikov sa zaradilo len 6\% - 109 opýtaných. Na základe prevažujúcich typov možno trnavskú populáciu zaradit' do tradičného typu nákupného správania.

Aj diferencovaný výsledok kontingencie vzt’ahu medzi vekom a nákupným typom potvrdil, že trnavská populácia je v nakupovaní tradičná. Zo segmentovaných výsledkov rozdelených do 36 skupín bolo 16 v modernej orientácii (typ A, B, C) a 20 v tradičnej (D, E, F, G). Najväčšie rozpätie nákupných typov a rozdiely vo vekových skupinách mali dve mestské časti Trnava-Sever a Modranka, kde zo 7 typov boli potvrdené štyri charakteristiky (B, C, D a E). Najmenšie nákupné rozdiely medzi vekovými skupinami boli identifikované v MČ Trnava-Východ, kde obyvatelia vekových skupín od 20 do 49 rokov boli mobilní pragmatici a od 50 a viac sporiví, ako i v MČ Trnava-Stred, kde mladšie ročníky do 29 rokov boli sporiví, 30-49 roční mobilní pragmatici a 50 a viac roční sporiví. V MČ Trnava-Západ sme zistili tri variácie nákupných typov, kde prekvapivo mladšie ročníky do 20 aj od 20 do 29 rokov boli v nakupovaní sporiví a naopak ročníky od 30-59 rokov nároční. Najstarší obyvatelia sa ako jediní v meste hlásili $\mathrm{k}$ nenáročným flegmatikom. V MČ Trnava-Juh sú prekvapivo mladšie ročníky konzervatívne, v skupine 20-49 roční mobilní pragmatici a 50 a viac roční sporiví.

$\mathrm{Na}$ základe výsledkov výskumu v oblasti nákupného správania $\mathrm{v}$ meste Trnava je pozoruhodné, že podl'a parametrov objektívneho posudzovania, ako je používanie automobilov (potvrdené u 66\% respondentov), preferovanie obchodných centier (dokonca pri nákupoch odevov 65\%) a vel'koplošných predajní (hypermarkety - 57\% opýtaných, supermarkety - 17\%) sa trnavská populácia správala moderne, avšak subjektívne samohodnotenie respondentmi v roku 2015 nepotvrdilo modernú, ale tradičnú orientáciu v nakupovaní.

\section{Pod'akovanie}

Príspevok bol spracovaný v rámci projektu VEGA č. 1/0799/14 „Geografické aspekty maloobchodnej siete velkých miest SR v nových trhových podmienkach" a projektu VEGA č. 1/0874/14 „Využitie neuromarketingu vo vizuálnom merchandisingu potravín".

\section{Literatúra}

BERČÍK, J. - HORSKÁ, E. 2017. Neuromarketing in food retailing. Wageningen: Wageningen Academic Publishers, 2017. 170 p. ISBN 978-90-8686-300-6.

BILKOVÁ, K. - KRIŽAN, F. - BARLÍK, P. 2015. Consumers preferences of shopping centers in Bratislava (Slovakia). In Human Geographies - Journal of Studies and Research in Human Geography. ISSN 1843-6587, 2015, vol. 10, no. 1, pp. 7-21. 
BLEHA, B. 2003. Pohlavná a veková štruktúra. Populačný vývoj v regiónoch. Bratislava, s. 69-76.

DENNIS, CH. - NEWMAN, A. - MARSLAND, D. 2005. Objects of Desire: Consumer Behaviour in Shopping Centres Choices. New York: Palgrave MacMillan, 2005. 267 p.

FIRAT, F. 1993. Gender and Consumption: Transcending the Feminine, Gender Issues and Consumer Behaviour. London, pp. 205-228.

FRANTÁL, B. - KLAPKA, P. - SIWEK, T. 2012. Lidské chování v prostoru a čase: teoreticko-metodologická východiska. In Sociologický časopis. ISSN 0038-0288, 2012, roč. 48, č. 5, s. 833-857.

GFK. 2015. [online]. Dostupné na internete: http://www.gfk.com/cz/

HAMALOVÁ, M. - TVRDOŇ, J. - ŽÁRSKA, E. 1996. Priestorová ekonomika. Bratislava: Ekonóm, 1996. 144 s. ISBN 80-225-0750-4.

JASUILEWICZ, A. 2012. Economic Crisis Influence on the Polish Consumer Behavior. [online]. Dostupné na intrnete: http://www.hippocampus.si/ ISBN/978-961-6832-32-8/contents.pdf.

KITA, P. - GROSSMANOVÁ, M. 2014. Reflection of Bratislava Retail Network in Selected Aspects of Consumer Behaviour. In Business: Theory and Practice. ISSN 1648-0627, 2014, vol. 15, no. 3, pp. 279- 284.

KRIŽAN, F. - BILKOVÁ, K. - KITA, P. - KUNC, J. - BARLÍK, P. 2015. Nákupné centrá v Bratislave a atribúty ovplyvňujúce preferencie spotrebitel'ov. In Geografický časopis. ISSN 0016-7193, 2015, roč. 67, č. 4, s. 341-357.

KUNC, J. - SZCZYRBA, Z. - FRANTÁL, B. - TONEV, P. 2012a. Nákupní spád, nákupní chování a nákupní centra: na př́íklade brnenské aglomerace (příspěvek ke studiu denních urbánních systémů). In Sociologický časopis. ISSN 00380288, 2012, roč. 48, č. 5, s. 879-910.

KUNC, J. - TONEV, P. - GREPLOVÁ, Z. - SZCZYRBA, Z. 2012b. Fenomén nákupních center $\mathrm{v}$ České republice. In 15th International Colloquium on Regional Sciences, Brno, Česko, s. 264-271- ISBN 978-80-210-5875-0.

KUNC, J. - FRANTÁL, B. - SIWEK, T. - HALÁS, M. - KLAPKA, P. SZCZYRBA, Z. - ZUSKÁČOVÁ, V. 2013. Časoprostorové modely nákupního chování české populace. Brno: Masarykova univerzita, 194 s. ISBN 978-80210-6020-3.

KUNC, J. - KRIŽAN, F. - BILKOVÁ, K. - BARLÍK, P. - MARYÁŠ, J. 2016. Are there differences in the attractiveness of dhopping centres? Experiences from the Czech and Slovak Republics. In Moravian Geographical Reports. ISSN 1210-8812, 2016, vol. 24, no. 1, pp. 27-41. DOI:10.1515/mgr-2013-0003. MARKECHOVÁ, D. - TIRPÁKOVÁ, A. - STEHLÍKOVÁ, B. 2011. Základy štatistiky pre pedagógov. Nitra: UKF v Nitre, 2011. 307 s. ISBN 978-80-8094899-3. 
MARYÁŠ, J. 2013. Vývojové tendence ve spádovosti za službami na př́íladě zázemí Brna. In 16th International Colloquium on Regional Sciences, Brno, Česko. s. 223-228. ISSN 1732-4254.

MARYÁŠ, J. - KUNC, J. - TONEV, P. - SZCZYRBA, Z. 2014. Shopping and service Related Travel in the Hinterland of Brno: Changes From the Socialist Period to the Present. In Moravian Geographical Reports. ISSN 1210-8812, vol. 22, no. 3, pp. 18-28.

METEŇKO, A. 2007. Manažment lokalizácie obchodných podnikov v novom ekonomickom prostredí. Košice: Ekonomika firiem, 2007, s. 533-549. ISBN 978-80-225-2482-7.

MITRÍKOVÁ, J. 2008. Geografické aspekty transformácie maloobchodu a nákupného správania sa na Slovensku (prípadové štúdie z miest Prešova Košice). Prešov: Prešovská univerzita, 2008. 213 s. ISBN 978-80-8068-922-3.

MITRÍKOVÁ, J. 2011. Vplyv globalizácie maloobchodu na nákupné správanie sa zákazníkov a ich akceptáciu vel'koplošných predajní. In Folia Geographica. ISSN 1336-6157, 2011, roč. 17, č. 52, s. 255-273.

MITRÍKOVÁ, J. - ŠENKOVÁ, A. - ANTOLÍKOVÁ, S. 2015. Application of the Huff model of shopping probability in the selected stores in Prešov (Prešov the Slovak republic). In Geographica Pannonica. vol. 19, no. 3, pp. 110-121.

OTNES, C. - McGRATH, M. A. 2001. Perceptions and realities of male shopping behaviour. In Journal of Retailing. vol. 77, no. 1, pp. 111-137.

REPASKÁ, G. - VILINOVÁ, K. - VOJTEK, M. 2016a. Spatial Distribution of Object of Commercial Suburbanization in Selected Localities of the Nitra Town. In 19th International Colloquium on Regional Sciences, Čejkovice, Česko, pp. 529-536. ISBN 978-80-210-8273-1.

REPASKÁ, G. - VILINOVÁ, K. - ŠOLCOVÁ, L. 2016b. Migration Trends and Their Impact in the District of Slovakia. In International Scientific Conference on Region in the Development of the Society, Brno, Česko, pp. 768-777.

SPILKOVÁ, J. 2012. Geografie maloobchodu a spotřeby - věda o nakupování. Praha: Karolinum, 2012. 245 s. ISBN 9788024619514.

SPILKOVÁ, J. 2016. Teenage overweight and obesity: A pilot study of obesogenic and obesoprotective environments in the Czech Republik. In Moravian Geographical Reports. ISSN 1210-8812, 2016, vol. 24, no. 1, pp. 55-64.

SZCZYRBA, Z. - FIEDOR, D. 2014. Vývoj velkoplošného maloobchodu Olomouce a výzkum nákupního chování. In 17th International Colloquium on Regional Sciences, Brno, Česko, pp. 740-748. ISBN 978-80-210-6840-7.

ŠTOFILOVÁ, J. 2003. Vel'koplošné predajne na Slovensku. In Marketingová panoráma. roč. 1, č. 4, s. 24-25.

TELLER, CH. - ELMS J. R. 2012. Urban Place Marketing and Retail Agglomeration Customers. In Journal of Marketing Management. vol. 28, no. 5-6, pp. 546-567. 
TELLER, CH. - THOMSON, J. A. 2012. Gender Differences of Shoppers in the Marketing and Management of Retail Agglomerations'. In The Service Industries Journal. vol. 32, no. 6, pp. 961-980.

TELLER, CH. - ELMS, J. R. - THOMSON, J. A. - PADDISON, A. R. 2010. Place Marketing and Urban Retail Agglomerations: An examination of shoppers place attractiveness perceptions. In Place Branding and Public Diplomacy. vol. 6, no. 2, pp. 124-133.

TELLER, CH. - KOTZAB, H. 2004. Marketing Aspects of retail Agglomerations: Consumer Logistics. Vienna: Vienna University of Economics \& Business Administration.

TREMBOŠOVÁ, M. 2009. Nákupné správanie nitrianskej populácie. In GeoInformation. ISSN 1336-7234, 2009, roč. 5, č. 1, s. 130-133.

TREMBOŠOVÁ, M. 2010. Vybrané aspekty transformácie maloobchodu v meste Nitra v rokoch 1992 - 2008. In Geografický časopis. ISSN 0016-7193, 2010, roš. 62 , č. 1 , s. 49-73.

TREMBOŠOVÁ, M. - DUBCOVÁ, A. 2016. Atraktivita maloobchodnej vybavenosti vybraných mestských častí mesta Nitra - Klokočina a Chrenová. (v tlači)

TREMBOŠOVÁ, M. - DUBCOVÁ, A. - KRAMÁREKOVÁ, H. 2016. Consumers shopping behaviour in the Nitra city. The agri-food value chain: challenges for natural resources management and society. Nitra: UKF v Nitre, 2016. $128 \mathrm{p}$.

VESELOVSKÝ, J. - ŠOLCOVÁ, L. 2011. Long-term Unemployment as One of Poverty Indicator on the Example of Nitra Region. In Geographia Cassoviensis. vol. 5, no. 1. pp. 119-124.

\section{MODELS OF THE SHOPPING BEHAVIOR OF RESIDENTS OF URBAN PARTS IN THE TRNAVA CITY}

\section{Summary}

In the model of shopping behavior of respondents from a range of seven types - suggestible, demanding, mobile pragmatic, cautious conservative, thrifty, loyal customer, and undemanding phlegmatic the most numerous group was the thrifty shopping type ( $26 \%$ of respondents). The second place was taken by the mobile pragmatist whose characteristics was the most fitting for $19 \%$ of respondents and $16 \%$ of respondents ranked themselves among demanding customers. Cautious conservatives were represented by $12 \%$ which were followed by loyal group of shoppers (12\%). Suggestible shoppers were $9 \%$ of respondents and the last group of undemanding phlegmatics considered only $6 \%$ of respondents. Based on the prevailing types, the Trnava population can be classified to the traditional type of shopping behavior. Moreover, the differentiated result of 
contingency of the relationship between age and shopping type confirmed that the Trnava population can be regarded as traditional.

Based on the results of research in the field of shopping behavior in Trnava city, it is noteworthy that according to the objective assessment such as the use of cars (confirmed by $66 \%$ of respondents), preferring shopping centers (even for purchases of clothing and footwear by 79\%) and large-scale outlets (hypermarkets by $57 \%$ ), the Trnava population behaved as modern. On the other hand, the subjective self-assessment by respondents in 2015 did not confirm the modern, but traditional orientation for shopping.

\section{RNDr. Miroslava Trembošová, PhD.}

Katedra geografie a regionálneho rozvoja FPV UKF v Nitre

Trieda A. Hlinku 1, 94974 Nitra

E-mail:mtrembosova@ukf.sk

\section{Mgr. Marta Máčajová}

Úrad sociálnych vecí a rodiny Levice

L. Štúra 53, 93403 Levice

E-mail: macajova.marta@gmail.com

\section{Mgr. Matej Močko}

Katedra ekológie a environmentalistiky FPV UKF v Nitre

Trieda A. Hlinku 1, 94974 Nitra

E-mail: matej.mocko@ukf.sk 